\title{
Public debt and economic growth: contemporary evidence from a developing economy
}

\author{
Sam Kris Hilton
}

\author{
Department of Public Relations Management, University of Professional Studies, \\ Accra, Ghana
}

\section{Public debt and economic growth}

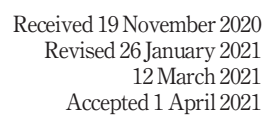

Received 19 November 2020 12 March 2021

Accepted 1 April 2021

\begin{abstract}
Purpose - Considering the continuous rise in the public debt stock of developing countries (particularly Ghana) with the unstable economic growth rate for the past decades and the recent borrowing because of the impact of COVID 19, this paper aims to examine the causal relationships between public debt and economic growth over time.

Design/methodology/approach - The paper uses a dynamic multivariate autoregressive-distributed lag (ARDL)-based Granger-causality model to test the causal relationships between public debt and economic growth [gross domestic product (GDP)]. Annual time-series data that spanned 1978-2018 were sourced from the World Bank Development Indicator database and the IMF fiscal Affairs Department Database and WEO.

Findings - The results reveal that public debt has no causal relationship with GDP in the short-run but there is unidirectional Granger causality running from public debt to GDP in the long run. Again, investment spending has a negative bi-directional causal relationship with GDP in the short-run but they have a positive bi-directional causal relationship in the long run. Conversely, no short-run causal relationship exists between government consumption expenditure and GDP but long-run Granger causality runs from government consumption expenditure to GDP. Finally, public debt has a positive impact on the inflation rate in the short run.

Practical implications - The findings imply that government(s) must ensure high fiscal discipline to serve as a precursor for the effective and efficient use of recent borrowing, that is, the loans should be used for highly prioritized projects (preferably investment spending) that are well evaluated and self-sustained to add positively to the GDP.

Originality/value - This paper provides contemporary findings to augment extant literature on public debt and economic growth by using variables and empirical models, which prior studies could not sufficiently cover in a developing country perspective and affirms that public debt contributes to GDP only in the long run.
\end{abstract}

Keywords GDP, Public debt, Government consumption expenditure, Investment spending,

Inflation rate, Population growth rate

Paper type Research paper

\section{Introduction}

Globally, financing governments' budgets require sustainable funding policy to stimulate economic growth. Usually, when tax revenues fall short of expenditure estimates of

(C) Sam Kris Hilton. Published in Asian Journal of Economics and Banking. Published by Emerald Publishing Limited. This article is published under the Creative Commons Attribution (CC BY 4.0) licence. Anyone may reproduce, distribute, translate and create derivative works of this article (for both commercial and non-commercial purposes), subject to full attribution to the original publication and authors. The full terms of this licence maybe seen at http://creativecommons.org/licences/by/4.0/ legalcode
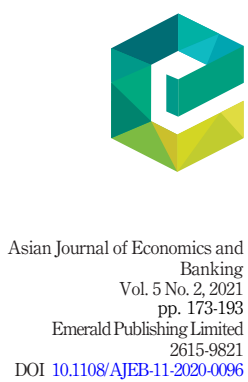
AJEB

5,2

governments, they have no option than to increase tax or borrow - internally or externally (Owusu-Nantwi and Erickson, 2016). When governments resort to borrowing which is the alternate way to avoid tax burdens, it leads to public debt (Ogunmuyiwa, 2010). Public debts are, therefore, both short-term and long-term loans sourced by governments to finance public expenditures as a result of inadequate public revenues. To respond to the global economic recessions after the Second World War, many economies (including developed and developing) resorted to borrowing either domestically or externally to fund budget deficits. These strives had led to the accumulation of public debt for many countries, resulting in the economic recession and debt crises experienced in the early 2000s by many developed and developing countries (Donayre and Taivan, 2017). As a result, academic and policy debate on the causal relationship between public debt and economic growth had been renewed (Gómez-Puig and Sosvilla-Rivero, 2018).

Research shows that it is highly improbable for a country to run a surplus budget, and therefore the acquisition of public debt becomes inevitable (Adom, 2016). It follows that the acquisition of public debt is not really a problem; nevertheless, building up public debt to unsustainable levels can stifle economic growth (Adom, 2016). For instance, available literature submits that unsustainable public debt reduces a country's competitiveness and increases a country's financial market susceptibility to international shocks which consequently impede economic growth (Cochrane, 2011; Castro et al., 2015). It also implies that, even though borrowing to finance public spending is not bad, it equally has an adverse effect on economic growth if not managed efficiently and effectively. For example, the global debt crises experienced in the mid-1970s and 1980s were attributed to poor debt management policies between low and middle-income countries (Marquez, 2000). Debt acquisition in these periods was very high and the servicing of debt became the core challenge for the emerging and less advanced economies because of the increase in shortterm loans to finance long-term projects without corresponding ability to fulfill debt obligations on time (Marquez, 2000).

Likewise, debtor countries were rolling over their huge debt because of the large balanceof-payment effect in the mid-1970 oil crisis which adversely affected economic development because developing economies strived to sustain growth rate and borrowed heavily so as to complete development projects (Stambuli, 1998). At this time, the allocation for most of the projects by governments was mismatched with the financing maturity structure where authorities take short-term loans and invest heavily in long-term projects, thereby making it difficult to retrieve these funds to settle their debt obligations (Krumm, 1985). During this period, most African governments who had never borrowed before took advantage of the Euromarkets platform to borrow huge amounts to finance their budgets (Krumm, 1985). In spite of the imminent debt crises, advanced economies were dreadfully willing to settle longterm credits of developing countries with shorter maturities, resulting in increased debt level of developing countries from $\$ 130 \mathrm{bn}$ in 1973 to about $\$ 612 \mathrm{bn}$ in 1982 (IMF, 1984).

Just like other developing countries, Ghana also has a long history of public debt traceable to the periods of global economic recessions and debt crises. As of 1957, Ghana has no record of public debt. In fact, in 1954, Ghana has a surplus budget of about $14.5 \%$ of GDP but recorded a deficit budget of $6.4 \%$ of GDP by 1965 . Similarly, public expenditure increased from $9.5 \%$ in 1957 to $25.8 \%$ in 1965 , resulting in public debt of $25.16 \%$ of GDP. After the overthrown of the Convention People's Party (CPP) government in 1966 and the government of Ghana under the National Liberation Council sought stabilization program support from the International Monetary Fund (IMF), the public debt stock decreased to $16.47 \%$ of GDP by 1975 . By 1994, Ghana's public debt rose from $27.5 \%$ in 1984 to $103 \%$ of GDP and further rose to $182 \%$ of GDP in 2000 with a corresponding growth rate of $3.7 \%$. 
The high public debt stock in 2000 caused Ghana to be classified as a heavily indebted poor country (HIPC) in 2001, where most of her debts were written off by the IMF and World Bank (World Bank, 2004). By 2008, Ghana moved from a low-income HIPC country to a lower-middle-income economy with a reduction in public debt of $182 \%$ in 2000 to $32 \%$ in 2008. Ghana's debt level started rising again from $26.2 \%$ of GDP in 2006 to $57.2 \%$ of GDP in 2016. As of December 2019, the public debt of Ghana stood at $63 \%$ of GDP (representing GH c218bn) (BoG, 2020). The continuous rise in public debt has been described as the consequence of the increase of public borrowing to finance government expenditures (Amponsah, 2015). A monetary policy committee report of the Bank of Ghana attributed the recent rise in public debt to the depreciation of the cedi and cleaning up of the financial sector (with a loan of $\mathrm{GH} \not 10.9 \mathrm{bn})$ (BoG, 2020).

However, what incessantly attracts the attention of researchers and economic policy analysts is the impact of these borrowings (both domestic and external) on the economic growth (gross domestic product (GDP)) of Ghana, particularly, when Ghana continues to experience an unstable growth rate with continuous rise in public debt. For instance, GDP increased from $3.7 \%$ (with public debt of $182 \%$ ) in 2000 to $8.4 \%$ (with public debt of $32 \%$ ) in 2008. By 2011, GDP rose to $14 \%$ (with non-oil GDP of $8.4 \%$ ) (IMF, 2015). Yet, the GDP declined steadily to $3.5 \%$ in 2016 (with public debt of $57.2 \%$ ) and rose to $8.1 \%$ in 2017 and started declining again alongside the rising in public debt to hit $6.5 \%$ in 2019 (with public debt of $63 \%$ ). Within a month of confirming COVID 19 in Ghana with over 4,000 positive cases as of May 8, 2020 (Ghana Health Service, 2020), the government resorted to borrowing from the World Bank and IMF with a successful $\$ 1$ bn IMF relief loan to finance revenue shortfalls. The total debt stock further rose to GHф236.1bn ending March 2020 (BoG, 2020) and it is projected to increase to nearly $70 \%$ of GDP with a projected growth rate of $1.5 \%$ by the close of 2020 (IMF, 2020).

Revealing a clear link between public debt and economic growth continues to attract the attention of researchers and practitioners with varied study outcomes. While some established a positive causal relationship between public debt and economic growth, others revealed an inverse causal relationship. For instance, the classical economic theorists suggest that debt-financed public expenditures do not fully offset the negative impact of the crowding out of the private investment, leading to economic decline (Domar, 1944). Thus, government borrowing from the domestic market causes liquidity crises and interest rate hikes which discourages private investment (Modigliani, 1961; Mankiw, 2000). On the other hand, Keynesian economic theorists argue that debt-financed public expenditures have a crowding-in effect, which causes a positive multiplier effect on national output or income (Elmendorf and Mankiw, 1999). Again, though empirical literature stressed the positive impact of public debt on economic growth (Barro, 1979; Krugman, 1988; Eberhardt and Presbitero, 2015; Ewaida, 2017; Huang et al., 2018), an inverse causal relationship between public debt and economic growth was also reported (Barro, 1990; Saint-Paul, 1992; Aizenmana et al., 2007; Adom, 2016; Ahlborn and Schweickert, 2016).

In spite of the considerable literature on public debt and economic growth, there is hitherto scanty contemporary literature on the phenomenon in Ghana. Again, the mixed outcomes of prior literature are indications that the debate on public debt and economic growth is an unending one. Furthermore, considering the continuous rise in the public debt of Ghana with unstable growth rate and the impact of COVID 19 on the Ghanaian economy which pushed the government to go in for $\$ 1 \mathrm{bn}$ IMF relief loan among other distressing developing countries in the Sub-Saharan Africa, the researcher argues that it is imperative to examine the trend in the public debt of Ghana alongside economic growth to ascertain the causal relationship between public debt and economic growth over time to provide 
AJEB

5,2

contemporary evidence of how public debt (especially recent borrowing) would likely impact on economic recovery programs in this global crisis from the perspective of a developing country.

This study contributes significantly to economic theories by providing empirical evidence of the usefulness of the Ricardian Equivalence Hypothesis (REH) and Keynesian economic theory as against the classical economic theory and modern monetary theory (MMT) in managing public debt in contemporary times, particularly during the COVID 19 era in a developing economy context. That is, recent borrowing will not have an effect on GDP in the short run but it will have a positive impact on GDP in the long run. Therefore, from developing economies perspective, government(s) must ensure high fiscal discipline to serve as a precursor for the effective and efficient use of recent borrowing (i.e. the loans should be used for highly prioritized projects, preferably infrastructure or investment spending) that are well evaluated and self-sustained to add positively to the GDP in the longrun.

\section{Literature review}

This aspect of the paper reviews theoretical and empirical literature underpinning public debt and economic growth. In regard to theoretical literature, four schools of thought (i.e. Classical, Keynesian, Ricardian and Modern Monetary) had made varied arguments on the causal relationship between public debt and economic growth. To begin with, the classical school of thought argues that public debt obstructs economic growth because it reduces both the financial discipline of the budget process and the private sector's access to credit (Broner et al., 2014). They further assert that public debt repayments, typically external debt, crowd out economic growth by discouraging private investment and dissuading potential foreign investors (Modigliani, 1961; Diamond, 1965; Krugman, 1988; Saungweme and Odhiambo, 2019).

Secondly, the Keynesian school of thought is considered a mono-causal theory of growth, which posits that debt-financed public expenditures have a fiscal multiplier effect on national output or income (Elmendorf and Mankiw, 1999). The Keynesian theory is underpinned by the "law of increasing state activity" hypothesis, which postulates that increased government spending enhances the domestic economic activity and crowds in private investment (Wagner, 1911; Ncanywa and Masoga, 2018). The view of the Keynesian economic theorists suggests that public debt withdraws cash from private investors, but then does not impact consumption because the borrowing funds are injected back into the economy to increase overall demand, perhaps, through wages and salaries and other capital expense (Onogbosele and Ben, 2016). Thus, Keynesian economic theorists ignored the challenge of financing budget deficits using either tax cuts or borrowing and emphasized frequent public interference to boost aggregate demand, jobs and production as fueled by government borrowing, either domestically or externally (Nwannebuike et al., 2016).

Thirdly, the REH stipulates that public debts have a neutral impact on economic growth (Ricardo, 1951; Barro, 1979, 1990; Afzal, 2012). This hypothesis is constructed on the assumption that variations in public expenditures and revenues are matched by changes in private savings (Kourtellos et al., 2013). The REH submits that regardless of the financing of public expenditures by debt or tax increase, the impact of the overall economic level on demand is identical (Ricardo, 1951). The theory posits that potential tax will allow debt repayment, that is, by the purchase of bonds issued by the government, individuals will boost their earnings (Ricardo, 1951; Barro, 1990). The REH further explains that when a government reduce taxation and decide to fund her budget deficits through a problem of bonds, households are generally sensitive to increasing consumption as they believe that the 
government would in future increase taxes so as to repay debts, thus, neither debts nor fiscal development has a lasting impact on economic growth (Afzal, 2012; Onogbosele and Ben, 2016).

Finally, the MMT postulates that public debt is merely money the government put into the economy and did not tax back (Mosler, 1993). The MMT suggests that comparing a government's budgets to that of an average household is inaccurate (Wray, 1998). The MMT argues that sovereign governments that issue debt in their own currency cannot be expected to default (Wray, 2015). This claim is buttressed by further arguments that the central banks of sovereign governments would consistently set interest rates near or at zero that would support deficit financing at lower economic growth rates (Driessen and Gravelle, 2019). Again, sovereign governments can print money as a substitute for taxes or borrowing to finance their expenditures (Mosler, 1993; Wray, 1998; Wray, 2015). Thus, governments' deficits would be small enough to limit inflation, thereby stimulating economic growth in the short-run (Driessen and Gravelle, 2019).

The available empirical literature on public debt and economic growth revealed mixed findings from both cross-country heterogeneity and time-frame considered. These findings addressed five main hypotheses on the causal relationship between public debt and economic growth.

To begin with, research support the hypothesis that the level of public indebtedness is determined by the pace of economic growth (Saungweme and Odhiambo, 2019). This assertion is underscored by the work of Donayre and Taivan (2017) which established that the causal relationship between public debt and real GDP growth is intrinsic to each country. They further disclosed that in highly market-driven economies, the direction of causality is from low GDP growth to public debt; however, in more socialist states, causality runs either from low GDP growth to public debt accumulation or is bi-directional (Donayre and Taivan, 2017).

Again, there are empirical studies that confirm the hypothesis that economic growth stagnation is caused by high public debt. This hypothesis posits that public debt crowds out private investment through the high cost of capital and consequently strikes economic growth (Reinhart et al., 2012; Kobayashi, 2015; Anning et al., 2016; Kobayashi and Shirai, 2017). Thus, excessive public debt reduces GDP growth rates by discouraging private sector investment (Lamont, 1995; Kobayashi and Shirai, 2017).

Furthermore, the third hypothesis that the direction of causality between public debt and economic growth is bi-directional states. This hypothesis is sometimes called the feedback hypothesis and it is empirically supported by Amoateng and Amoako-Adu (1996), Abbas and Christensen (2007), Ferreira (2009), Owusu-Nantwi and Erickson (2016) and Donayre and Taivan (2017).

Additionally, many empirical studies show consistency with the hypothesis that public debt has a positive causal relationship with economic growth. This hypothesis suggests that economic growth increase as the public debt level rises. Studies that support this view include Barro, (1979, 1990), Krugman (1988), Eberhardt and Presbitero (2015), Ewaida (2017), Huang et al. (2018) and Saungweme and Odhiambo (2019).

Finally, the fifth hypothesis suggests that there is no causality between public debt and economic growth. This hypothesis is also known as the neutral hypothesis or debt-growth neutrality hypothesis and it is empirically held by Ahmed et al. (2000), Reinhart and Rogoff (2010), Jalles (2011) and Panizza and Presbitero (2014).

A summary of the aforementioned hypotheses is depicted in Table 1 . The table highlights selected recent empirical studies and their model estimation methods alongside their findings to buttress the five hypotheses reviewed.
Public debt and economic growth 

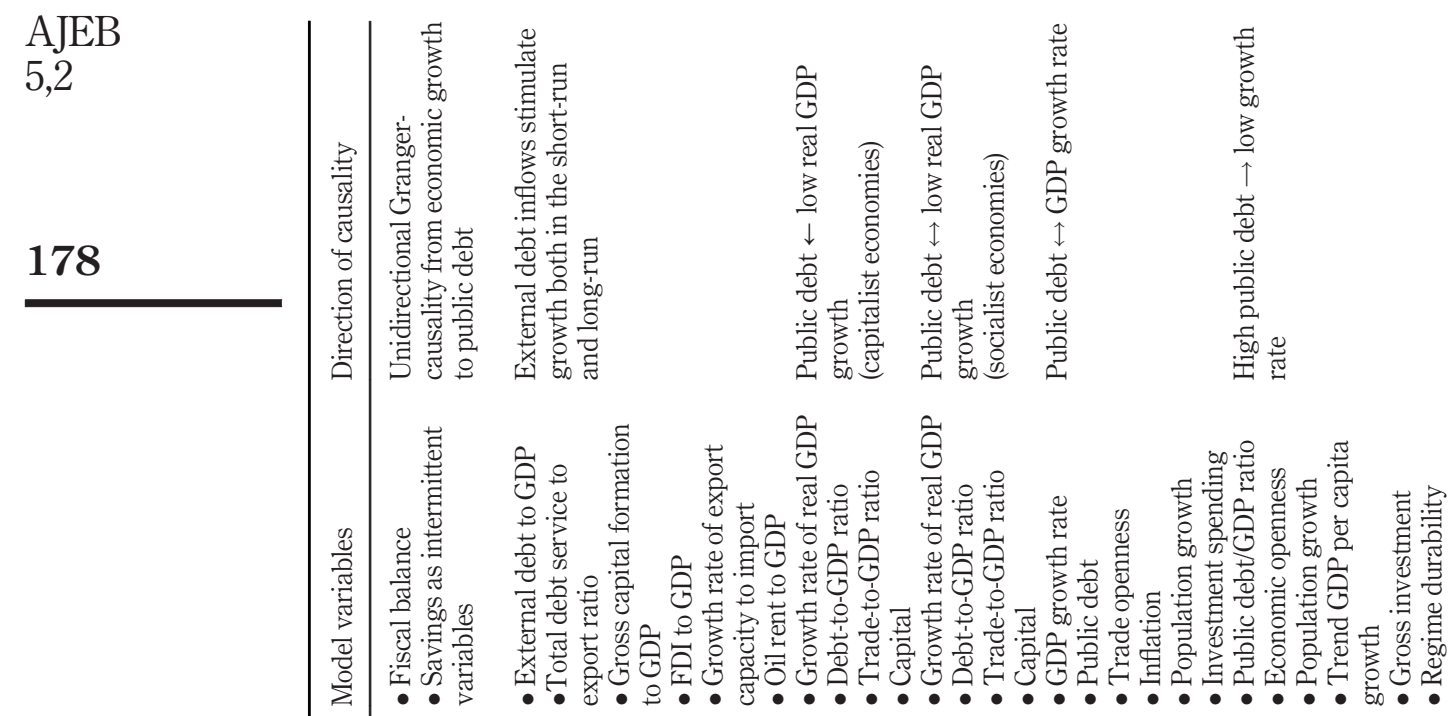

Table 1.

Empirical studies on the causal relationship between public debt and economic growth

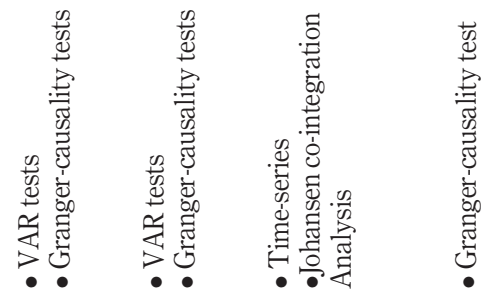

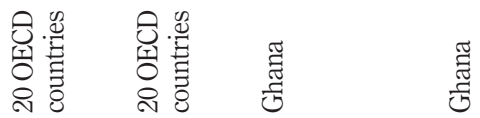

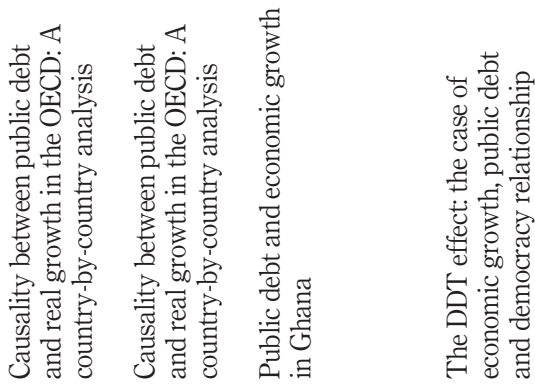

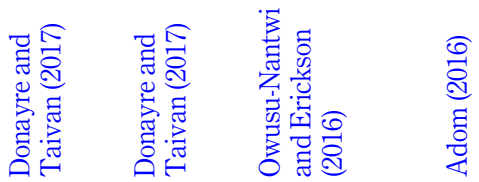




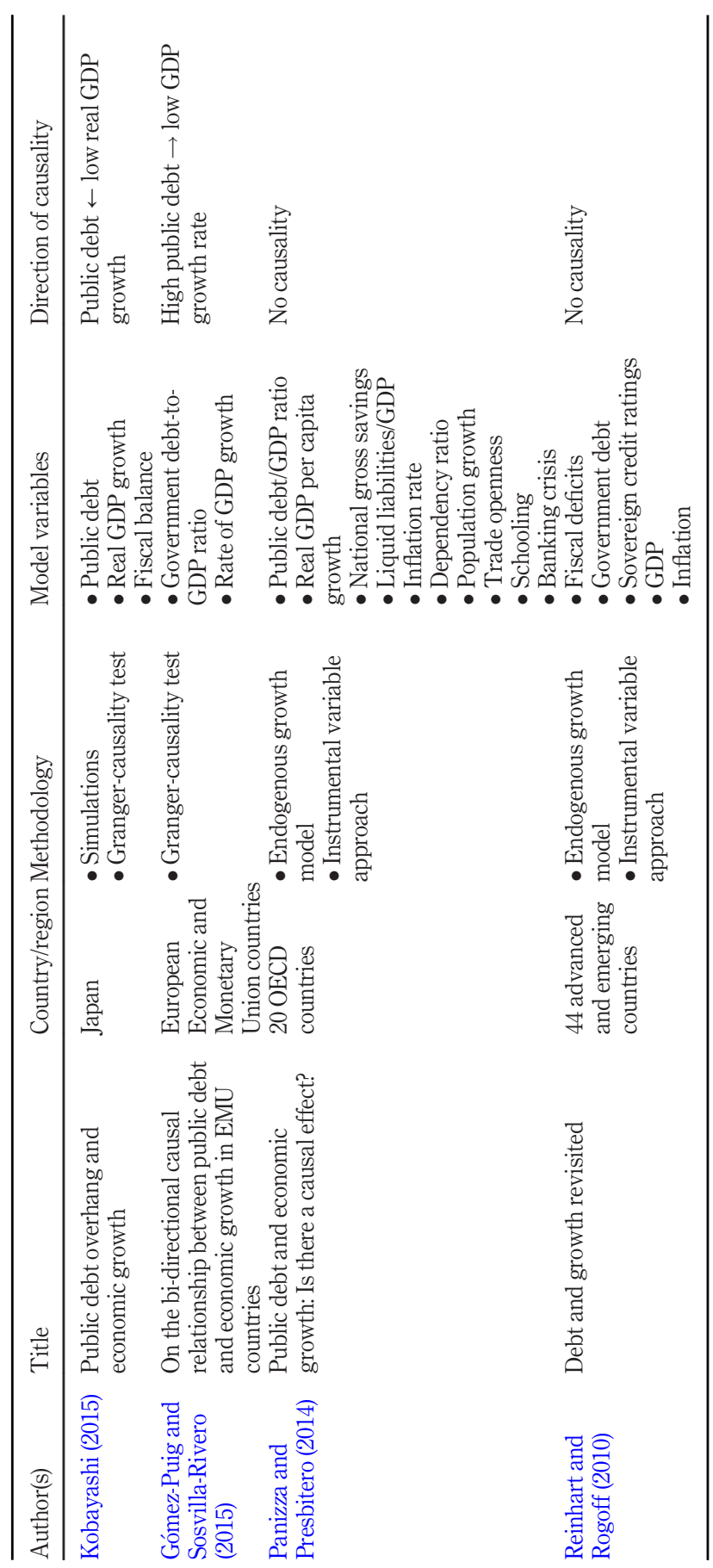

Public debt and economic growth 
AJEB

5,2

\section{Model estimation and data}

The study used dynamic multivariate autoregressive-distributed lag (ARDL)-based Granger-causality model to test the causal relationships between public debt and economic growth (GDP) in Ghana. To address the limitations of prior (e.g. omitted-variable-bias), this study includes other relevant variables such as government consumption expenditure, inflation rate, investment spending, trade open and population growth which featured studies in other jurisdictions. The ARDL bounds test prescribed by Pesaran et al. (2001) was used to determine cointegration among the regression variables. The error correction model (ECM) was subsequently estimated to establish the Granger causality in the long run. The ARDL and ECM are more efficient, particularly with a small sample size as being used in this study compared to the Johansen cointegration model which is suitable for a large sample size. The use of these estimation models is justified by prior empirical studies (Pesaran et al., 2001; Kumar and Woo, 2010) and similarly applied to test causality between public debt and economic growth in a developing economy (Zambia) (Saungweme and Odhiambo, 2019). Finally, these models appropriately eliminate spurious correlations and increase the general validity of the causation test (Lutkepohl, 1982).

\subsection{Model specification}

The impact of public debt on economic growth has been widely examined particularly within the context of four economic theories (i.e. classical, Keynesian, REH and MMT). The propositions of these theories have led to five hypotheses in empirical literature with inconclusive findings. For easy comparison of the empirical results of this study to prior literature, the ARDL model and ECM were estimated on short-run and long-run causalities to support or depart from existing literature in the case of Ghana. The summary hypotheses of the theories are that:

- causality run from public debt (positively or negatively) to GDP (i.e. unidirectional);

- causality run from GDP to public debt (i.e. unidirectional);

- causality run from and to each other (i.e. bi-directional) and

- no causality (i.e. neutrality). These hypotheses are tested in both short-run and longrun periods.

3.1.1 Autoregressive-distributed lag short-run model specification. The ARDL short-run model is specified for all the regression variables (i.e. GDP, public debt, government consumption expenditure, inflation rate, investment spending, trade openness and population growth rate). Each variable is estimated as the dependent variable in the ARDLbased Granger-causality model. In all, seven short-run equations are estimated as follows:

$$
\begin{aligned}
\Delta G D P_{t}= & \alpha_{01}+\sum_{i=1}^{p} \alpha_{1 i} \Delta G D P_{t-i}+\sum_{i=1}^{q} \alpha_{2 i} \Delta P D_{t-1}+\sum_{i=1}^{q} \alpha_{3 i} \Delta G O V E_{t-1} \\
& +\sum_{i=1}^{q} \alpha_{4 i} \Delta I N F_{t-1}+\sum_{i=1}^{q} \alpha_{5 i} \Delta I N V_{t-1}+\sum_{i=1}^{q} \alpha_{6 i} \Delta O P E N_{t-1} \\
& +\sum_{i=1}^{q} \alpha_{7 i} \Delta P O P G_{t-i}+\mu_{1 t}
\end{aligned}
$$




$$
\begin{aligned}
& \Delta P D_{t}=\alpha_{02}+\sum_{i=1}^{p} \alpha_{1 i} \Delta P D_{t-i}+\sum_{i=1}^{q} \alpha_{2 i} \Delta G D P_{t-1}+\sum_{i=1}^{q} \alpha_{3 i} \Delta G O V E_{t-1} \\
& +\sum_{i=1}^{q} \alpha_{4 i} \Delta I N F_{t-1}+\sum_{i=1}^{q} \alpha_{5 i} \Delta I N V_{t-1}+\sum_{i=1}^{q} \alpha_{6 i} \Delta O P E N_{t-1} \\
& +\sum_{i=1}^{q} \alpha_{7 i} \Delta P O P G_{t-i}+\mu_{2 t} \\
& \Delta G O V E_{t}=\alpha_{03}+\sum_{i=1}^{p} \alpha_{1 i} \Delta G O V E_{t-i}+\sum_{i=1}^{q} \alpha_{2 i} \Delta G D P_{t-1}+\sum_{i=1}^{\mathrm{q}} \alpha_{3 i} \Delta P D_{t-1} \\
& +\sum_{i=1}^{q} \alpha_{4 i} \Delta I N F_{t-1}+\sum_{i=1}^{q} \alpha_{5 i} \Delta I N V_{t-1}+\sum_{i=1}^{q} \alpha_{6 i} \Delta O P E N_{t-1} \\
& +\sum_{i=1}^{q} \alpha_{7 i} \Delta P O P G_{t-i}+\mu_{3 t} \\
& \Delta I N F_{t}=\alpha_{04}+\sum_{i=1}^{p} \alpha_{1 i} \Delta I N F_{t-i}+\sum_{i=1}^{q} \alpha_{2 i} \Delta G D P_{t-1}+\sum_{i=1}^{q} \alpha_{3 i} \Delta P D_{t-1} \\
& +\sum_{i=1}^{q} \alpha_{4 i} \Delta G O V E_{t-1}+\sum_{i=1}^{q} \alpha_{5 i} \Delta I N V_{t-1}+\sum_{i=1}^{q} \alpha_{6 i} \Delta O P E N_{t-1} \\
& +\sum_{i=1}^{q} \alpha_{7 i} \Delta P O P G_{t-i}+\mu_{4 t} \\
& \Delta I N V_{t}=\alpha_{05}+\sum_{i=1}^{p} \alpha_{1 i} \Delta I N V_{t-i}+\sum_{i=1}^{q} \alpha_{2 i} \Delta G D P_{t-1}+\sum_{i=1}^{q} \alpha_{3 i} \Delta P D_{t-1} \\
& +\sum_{i=1}^{q} \alpha_{4 i} \Delta G O V E_{t-1}+\sum_{i=1}^{q} \alpha_{5 i} \Delta I N F_{t-1}+\sum_{i=1}^{q} \alpha_{6 i} \Delta O P E N_{t-1} \\
& +\sum_{i=1}^{q} \alpha_{7 i} \Delta P O P G_{t-i}+\mu_{5 t} \\
& \Delta O P E N_{t}=\alpha_{06}+\sum_{i=1}^{p} \alpha_{1 i} \Delta O P E N_{t-i}+\sum_{i=1}^{q} \alpha_{2 i} \Delta G D P_{t-1}+\sum_{i=1}^{q} \alpha_{3 i} \Delta P D_{t-1} \\
& +\sum_{i=1}^{q} \alpha_{4 i} \Delta G O V E_{t-1}+\sum_{i=1}^{q} \alpha_{5 i} \Delta I N F_{t-1}+\sum_{i=1}^{q} \alpha_{6 i} \Delta I N V_{t-1} \\
& +\sum_{i=1}^{q} \alpha_{7 i} \Delta P O P G_{t-i}+\mu_{6 t}
\end{aligned}
$$

Public debt and economic growth 
AJEB

5,2

182

$$
\begin{aligned}
\Delta P O P G_{t}= & \alpha_{07}+\sum_{i=1}^{p} \alpha_{1 i} \Delta P O P G_{t-i}+\sum_{i=1}^{q} \alpha_{2 i} \Delta G D P_{t-1}+\sum_{i=1}^{q} \alpha_{3 i} \Delta P D_{t-1} \\
& +\sum_{i=1}^{q} \alpha_{4 i} \Delta G O V E_{t-1}+\sum_{i=1}^{q} \alpha_{5 i} \Delta I N F_{t-1}+\sum_{i=1}^{q} \alpha_{6 i} \Delta I N V_{t-1} \\
& +\sum_{i=1}^{q} \alpha_{7 i} \Delta O P E N_{t-i}+\mu_{7 t}
\end{aligned}
$$

where

$\mathrm{GDP}_{\mathrm{t}}=$ annual GDP growth rate in period $\mathrm{t}$;

$\mathrm{PD}_{\mathrm{t}}=$ total public debt in period $\mathrm{t}$;

$\mathrm{GOVE}_{\mathrm{t}}=$ government consumption expenditure in period $\mathrm{t}$;

$\mathrm{INF}_{\mathrm{t}}=$ inflation rate in period $\mathrm{t}$;

$\mathrm{INV}_{\mathrm{t}}=$ investment spending in period $\mathrm{t}$;

$\mathrm{OPEN}_{\mathrm{t}}=$ trade openness in period $\mathrm{t}$;

$\mathrm{POPG}_{\mathrm{t}}=$ population growth rate in period $\mathrm{t}$;

$\alpha_{O}-\alpha_{7}=$ respective constants;

$\alpha_{1 i}-\alpha_{7 i}=$ respective regression coefficients; $\Delta$ denotes change;

$\mu_{1 t}-\mu_{7 t}=$ mutually independent white-noise residuals;

$p$ and $q=$ lag lengths and $t$ is the time period.

3.1.2 Error correction model long-run model specification. The ARDL bounds test records two cointegration vectors (i.e. $\mathrm{GDP}_{\mathrm{t}}$ and $\mathrm{INV}_{\mathrm{t}}$ ), meaning that there is the existence of long-run relationships. Hence, ECM long-run model is specified as follows:

$$
\begin{aligned}
\Delta G D P_{t}= & \alpha_{0}+\sum_{i=1}^{p} \alpha_{1 i} \Delta G D P_{t-i}+\sum_{i=1}^{q} \alpha_{2 i} \Delta P D_{t-1}+\sum_{i=1}^{q} \alpha_{3 i} \Delta G O V E_{t-1}+\sum_{i=1}^{q} \alpha_{4 i} \Delta I N F_{t-1} \\
& +\sum_{i=1}^{q} \alpha_{5 i} \Delta I N V_{t-1}+\sum_{i=1}^{q} \alpha_{6 i} \Delta O P E N_{t-1}+\sum_{i=1}^{q} \alpha_{7 i} \Delta P O P G_{t-i} \\
& +\lambda E C T_{t-1}+\mu_{1 t} \\
\Delta I N V_{t}= & \beta_{0}+\sum_{i=1}^{p} \beta_{1 i} \Delta I N V_{t-i}+\sum_{i=1}^{q} \beta_{2 i} \Delta G D P_{t-1}+\sum_{i=1}^{q} \beta_{3 i} \Delta P D_{t-1}+\sum_{i=1}^{q} \beta_{4 i} \Delta G O V E_{t-1} \\
& +\sum_{i=1}^{q} \beta_{5 i} \Delta I N F_{t-1}+\sum_{i=1}^{q} \beta_{6 i} \Delta O P E N_{\mathrm{t}-1}+\sum_{i=1}^{q} \beta_{7 i} \Delta P O P G_{t-i} \\
& +\lambda E C T_{t-1}+\mu_{2 t}
\end{aligned}
$$

where

$\mathrm{GDP}_{\mathrm{t}}=$ annual GDP growth rate in period $\mathrm{t}$;

$\mathrm{PD}_{\mathrm{t}}=$ total public debt in period $\mathrm{t}$;

$\mathrm{GOVE}_{\mathrm{t}}=$ government consumption expenditure in period $\mathrm{t}$;

$\mathrm{INF}_{\mathrm{t}}=$ inflation rate in period $\mathrm{t}$;

$\mathrm{INV}_{\mathrm{t}}=$ investment spending in period $\mathrm{t}$;

$\mathrm{OPEN}_{\mathrm{t}}=$ trade openness in period $\mathrm{t}$;

$\mathrm{POPG}_{\mathrm{t}}=$ population growth rate in period $\mathrm{t}$; 
$\alpha_{O}$ and $\beta_{O}=$ respective constants;

$\alpha_{1}-\alpha_{7}$ and $\beta_{1}-\beta_{7}=$ respective regression coefficients; $\Delta$ denotes change;

$\lambda=$ coefficient of $\mathrm{ECT}_{\mathrm{t}-1}$;

$\mathrm{ECT}_{\mathrm{t}-1}=$ error-correction term lagged once;

Public debt and economic growth

$\mu_{1 t}$ and $\mu_{2 t}=$ mutually independent white-noise residuals;

$p$ and $q=$ lag lengths and $t$ is the time period.

3.2 Unit root test, cointegration test and lag length selection criterion

The unit root test is run to test the stationarity of the variables used. Research shows that time-series data exhibit non-stationary tendencies, and therefore spurious correlations may show up among variables, which are non-stationary over time (Granger and Newfold, 1974; Phillips, 1986). Thus, the Augmented Dickey-Fuller (ADF) has been used to test the standard unit root in the data (Dickey and Fuller, 1981). The results of the unit root test, which are shown in Table 2, indicate that the series is stationary thereby meeting the condition for the cointegration test.

Subsequently, the ARDL bounds test is run to check the presence of cointegration among regression variables using an F-statistic and critical value (i.e. I0 Bound and I1 Bound). The result of the ARDL bounds test is depicted in Table 3. The test reveals only two cointegration vectors (i.e. $\mathrm{GDP}_{\mathrm{t}}$ and $\mathrm{INV}_{\mathrm{t}}$ ). The lag length is selected using Schwarz Information Criterion (SIC) and the result is depicted in Table 4.

\begin{tabular}{llclr}
\hline & \multicolumn{2}{c}{ Intercept and no trend } & \multicolumn{2}{c}{ Intercept and trend } \\
Variables & Levels & First difference & \multicolumn{1}{c}{ Levels } & First difference \\
\hline $\mathrm{GDP}_{\mathrm{t}}$ & $-3.526^{* * * *}$ & $-8.448^{* * * *}$ & $-4.643^{* * * *}$ & $-8.276^{* * * *}$ \\
$\mathrm{PD}_{\mathrm{t}}$ & -1.344 & $-5.305^{* * *}$ & -1.781 & $-5.233^{* * * *}$ \\
$\mathrm{GOVE}_{\mathrm{t}}$ & $-3.296^{* * *}$ & $-6.732^{* * *}$ & $-3.262^{*}$ & $-6.358^{* * * *}$ \\
$\mathrm{INF}_{\mathrm{t}}$ & $-4.742^{* * *}$ & $-13.053^{* * *}$ & $-6.753^{* * *}$ & $-12.895^{* * * *}$ \\
$\mathrm{INV}_{\mathrm{t}}$ & $-2.794^{*}$ & $-4.591^{* * *}$ & -2.648 & $-4.729^{* * * *}$ \\
$\mathrm{OPEN}_{\mathrm{t}}$ & -1.632 & $-5.785^{* * *}$ & -1.535 & $-5.952^{* * * *}$ \\
$\mathrm{POPG}_{\mathrm{t}}$ & 0.256 & $-4.164^{* * *}$ & $-3.684^{* *}$ & $-3.871^{* *}$
\end{tabular}

Notes: *;* and ***signifies the rejection of the null hypothesis of non-stationarity at 10,5 and $1 \%$ significance levels, respectively

Table 2.

$\mathrm{ADF}$ unit root test

\begin{tabular}{lcll}
\hline Dependent variable & $F$-statistic & Cointegration & Decision \\
\hline GDP & 13.62423 & Yes & Estimate ECM (long-run model) \\
PD & 2.019001 & No & Estimate ARDL (short-run model) \\
GOVE & 2.670415 & No & Estimate ARDL (short-run model) \\
INF & 1.607226 & No & Estimate ARDL (short-run model) \\
INV & 6.193958 & Yes & Estimate ECM (long-run model) \\
OPEN & 0.976022 & No & Estimate ARDL (short-run model) \\
POPG & 2.195038 & No & Estimate ARDL (short-run model)
\end{tabular}

Notes: Critical values (I0 bound) are 2.12, 2.45 and 3.15 and critical values (I1 bound) are 3.23, 3.61 and 4.43; critical values are significant at 10,5 and $1 \%$, respectively

Table 3.

ARDL bounds test 
AJEB

5,2

184

\subsection{Data}

The paper used annual time series data that spanned 1978-2018. Data on all the regression variables including annual GDP growth rate as a measure of economic growth, government consumption expenditure as a percent of GDP, investment spending as a percent of GDP, trade openness as a percent of GDP, inflation rate, population growth rate are sourced from the World Bank Development Indicator database (World Bank, 2020), except data on total public debt as a percent of GDP that is sourced from the IMF fiscal Affairs Department Database and WEO (IMF, 2020). Stationarity tests were carried out on the data before further analysis was done.

\section{Results and discussion \\ 4.1 Unit roots test}

The study used ADF to test the unit-roots. The results in Table 2 depict the unit root test with intercept and no trend, as well as intercept and trend. The results indicate that all the time series variables are integrated of order one as the ADF test statistics are all significant at first difference. As the ADF confirmed the stationarity of all the series variables at order one, the ARDL model and ECM were estimated.

\subsection{Autoregressive-distributed lag model and error correction model}

4.2.1 Autoregressive-distributed lag bounds test for cointegration. The ARDL bounds test is run to determine the cointegration among the study variables. The results are shown in Table 3. The test reveals two cointegration vectors, thus the null hypothesis (i.e. no long-run relationships exist) is rejected in this case. Hence, ECM can be estimated to establish the long-run Granger causality between the dependent variables $\left(\mathrm{GDP}_{t}\right.$ and $\left.\mathrm{INV}_{t}\right)$ and the exogenous variables. On the other hand, the null hypothesis is accepted for $\mathrm{PD}_{\mathrm{t}}, \mathrm{GOVE}_{\mathrm{t}}$, $\mathrm{INF}_{\mathrm{t}}, \mathrm{OPEN}_{\mathrm{t}}$ and $\mathrm{POPG}_{\mathrm{t}}$, meaning that no long-run relationship exists between them and the exogenous variables. Hence, only ARDL short-run models can be estimated for these variables.

4.2.2 Lag length selection criterion. As the series is stationary at order one and the cointegration vectors have been determined, the researcher proceeded to determine the lag length for the ARDL model and ECM. This study used Schwarz Information Criterion (SIC) to select the lag length. Table 4 shows the summary result for the lag length selected. It indicates that $\mathrm{GDP}_{t}, \mathrm{PD}_{\mathrm{t}}, \mathrm{GOVE}_{\mathrm{t}}, \mathrm{INF}_{\mathrm{t}}, \mathrm{INV}_{\mathrm{t}}, \mathrm{OPEN}_{\mathrm{t}}$ and $\mathrm{POPG}_{\mathrm{t}}$, respectively, have lag lengths of 1, 2, 1, 2, 2, 3 and 4. Therefore, the ARDL model and ECM estimations depended on these lag lengths.

Table 4.

Lag length selection test

\begin{tabular}{lcc}
\hline Dependent variable & Lag length & Schwarz information criterion (SIC) \\
\hline $\mathrm{GDP}_{\mathrm{t}}$ & 1 & $4.198211^{*}$ \\
$\mathrm{PD}_{\mathrm{t}}$ & 2 & $7.434926^{*}$ \\
$\mathrm{GOVE}_{\mathrm{t}}$ & 1 & $4.221904^{*}$ \\
$\mathrm{INF}_{\mathrm{t}}$ & 2 & $7.970828^{*}$ \\
$\mathrm{INV}_{\mathrm{t}}$ & 2 & $5.788110^{*}$ \\
$\mathrm{OPEN}_{\mathrm{t}}$ & 3 & $7.827804^{*}$ \\
$\mathrm{POPG}_{\mathrm{t}}$ & 4 & $-5.619442^{*}$ \\
Note: & Indicates lag order selected by the criterion & \\
\hline
\end{tabular}


4.2.3 Autoregressive-distributed lag-Granger short-run causality. The short-run causal relationships among the regression variables are examined and the results are presented in Table 5. The study adopted the ARDL short-run model to test the short-run Granger causality. The results show that in exception of investment spending, there is no short-run causal relationship running from public debt, government consumption expenditure, inflation rate, trade openness and population growth rate to GDP. It implies that in the shortrun only investment spending has a significant negative causal relationship with GDP. In regard to public debt, there is a negative short-run causal relationship running from investment spending and trade openness to public debt. However, GDP, government consumption expenditure, inflation rate and population growth rate do not cause public debt in the short run. Again, there is no short-run causal relationship running from the exogenous variables to government consumption expenditure except inflation rate (with negative relationship), while none of the exogenous variables causes inflation rate and trade openness in the short-run. However, all the exogenous variables cause investment spending in the short-run with GDP, inflation rate, trade openness and population growth rate having negative relationships whereas public debt and government consumption expenditure show positive relationships. Finally, there is a negative causal relationship running from GDP, public debt and investment spending to population growth rate while a positive causal relationship runs from government consumption expenditure and inflation rate to population growth rate. Meanwhile, trade openness has no causal relationship with the population growth rate.

Focusing on the principal variables (i.e. GDP and public debt), the results imply that there is no short-run causality from public debt to GDP and vice versa. This empirical finding suggests that, in the short-run, no causal relationship exist between public debt and GDP, which is consistent with the neutrality proposition of the REH theory (Ricardo, 1951) but disagrees with the short-run causal relationship assertion of the MMT (Mosler, 1993), classical school of thought (Modigliani, 1961) and Keynesian school of thought (Elmendorf

\begin{tabular}{|c|c|c|c|c|c|c|c|c|}
\hline \multirow[t]{2}{*}{$\begin{array}{l}\text { Dependent } \\
\text { variable }\end{array}$} & \multicolumn{7}{|c|}{$\begin{array}{l}\text { Independent variables } \\
\text { Coefficients [ } p \text {-value }]\end{array}$} & \multirow[t]{2}{*}{$\begin{array}{c}E C T_{t-1} \\
{[t \text {-statistics }]}\end{array}$} \\
\hline & $G P D_{t}$ & $P D_{t}$ & $G O V E_{t}$ & $I N F_{t}$ & $I N V_{t}$ & $O P E N_{t}$ & $P O P G_{t}$ & \\
\hline $\mathrm{GPD}_{\mathrm{t}}$ & - & $\begin{array}{c}0.004 \\
{[0.938]}\end{array}$ & $\begin{array}{l}-0.092 \\
{[0.679]}\end{array}$ & $\begin{array}{l}-0.003 \\
{[0.897]}\end{array}$ & $\begin{array}{c}-0.282 \text { *** } \\
{[0.009]}\end{array}$ & $\begin{array}{c}0.057 \\
{[0.180]}\end{array}$ & $\begin{array}{c}6.325 \\
{[0.580]}\end{array}$ & $\begin{array}{c}-1.077 \text { **** } \\
{[-3.726]}\end{array}$ \\
\hline $\mathrm{PD}_{\mathrm{t}}$ & $\begin{array}{l}-1.319 \\
{[0.215]}\end{array}$ & - & $\begin{array}{c}1.761 \\
{[0.200]}\end{array}$ & $\begin{array}{l}-0.073 \\
{[0.525]}\end{array}$ & $\begin{array}{c}-1.479^{*} \\
{[0.068]}\end{array}$ & $\begin{array}{c}-0.472^{* * *} \\
{[0.046]}\end{array}$ & $\begin{array}{c}-23.552 \\
{[0.798]}\end{array}$ & - \\
\hline $\mathrm{GOVE}_{\mathrm{t}}$ & $\begin{array}{c}0.036 \\
{[0.797]}\end{array}$ & $\begin{array}{c}0.003 \\
{[0.947]}\end{array}$ & - & $\begin{array}{c}-0.039 * \\
{[0.098]}\end{array}$ & $\begin{array}{l}-0.068 \\
{[0.490]}\end{array}$ & $\begin{array}{c}0.004 \\
{[0.914]}\end{array}$ & $\begin{array}{l}-3.712 \\
{[0.734]}\end{array}$ & - \\
\hline $\mathrm{INF}_{\mathrm{t}}$ & $\begin{array}{l}-0.162 \\
{[0.913]}\end{array}$ & $\begin{array}{c}0.982^{* * * *} \\
{[0.001]}\end{array}$ & $\begin{array}{c}1.602 \\
{[0.307]}\end{array}$ & - & $\begin{array}{l}-0.937 \\
{[0.169]}\end{array}$ & $\begin{array}{l}-0.326 \\
{[0.157]}\end{array}$ & $\begin{array}{c}-29.064 \\
{[0.763]}\end{array}$ & - \\
\hline $\mathrm{INV}_{\mathrm{t}}$ & $\begin{array}{c}-1.871^{* * * *} \\
{[0.000]}\end{array}$ & $\begin{array}{l}0.253^{* *} \\
{[0.043]}\end{array}$ & $\begin{array}{c}1.439 * * * \\
{[0.003]}\end{array}$ & $\begin{array}{c}-0.158^{* *} \\
{[0.039]}\end{array}$ & - & $\begin{array}{c}-0.125^{*} \\
{[0.070]}\end{array}$ & $\begin{array}{c}-59.789^{*} \\
{[0.056]}\end{array}$ & $\begin{array}{c}-1.029 * * * * \\
{[-3.181]}\end{array}$ \\
\hline $\mathrm{OPEN}_{\mathrm{t}}$ & $\begin{array}{c}0.875 \\
{[0.821]}\end{array}$ & $\begin{array}{c}0.372 \\
{[0.503]}\end{array}$ & $\begin{array}{l}-4.306 \\
{[0.251]}\end{array}$ & $\begin{array}{l}-0.057 \\
{[0.904]}\end{array}$ & $\begin{array}{l}-0.564 \\
{[0.672]}\end{array}$ & - & $\begin{array}{c}-73.609 \\
{[0.882]}\end{array}$ & - \\
\hline $\mathrm{POPG}_{\mathrm{t}}$ & $\begin{array}{c}-0.009 * \\
{[0.077]}\end{array}$ & $\begin{array}{c}-0.001^{*} \\
{[0.084]}\end{array}$ & $\begin{array}{l}0.006^{*} \\
{[0.078]}\end{array}$ & $\begin{array}{l}0.001^{*} \\
{[0.063]}\end{array}$ & $\begin{array}{c}-0.004^{*} \\
{[0.064]}\end{array}$ & $\begin{array}{c}0.000 \\
{[0.349]}\end{array}$ & - & - \\
\hline
\end{tabular}

Notes: $\mathrm{INV}_{\mathrm{t}}$ Granger causes $\mathrm{PD}_{\mathrm{t}}$ at lag $1 ; \mathrm{PD}_{\mathrm{t}}$ Granger causes $\mathrm{INF}_{\mathrm{t}}$ at lag $1 ; \mathrm{PD}_{\mathrm{t}}$ Granger causes $\mathrm{INV}_{\mathrm{t}}$ at lag 2; $\mathrm{INF}_{\mathrm{t}}$ Granger causes $\mathrm{INV}_{\mathrm{t}}$ at lag 1; POPG Granger causes $\mathrm{INV}_{\mathrm{t}}$ at lag 2; GOVE $\mathrm{t}_{\mathrm{t}}$ Granger causes $\mathrm{POPG}_{\mathrm{t}}$ at lag 1 and the other variables Granger cause $\mathrm{POPG}_{\mathrm{t}}$ at lag 2;*** and *** are significants at 10, 5 and $1 \%$, respectively

Public debt and economic growth

185

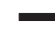


AJEB

5,2

and Mankiw, 1999). Compared to the empirical literature, this finding contradicts available literature on a short-run causal relationship between public debt and GDP (Barro, 1990; Eberhardt and Presbitero, 2015; Ahlborn and Schweickert, 2016). Thus, an increase or decrease in public debt would have no impact on GDP in the short-run, ceteris paribus.

It is instructive to note that among the regression variables, only investment spending has a bi-directional negative causal relationship with GDP in the short-run, meaning that investment spending and GDP negatively affect each other in the short run. Compared to public debt, there is a negative causal relationship running from investment spending to public debt while there is a positive causal relationship running from public debt to investment spending. Furthermore, government consumption expenditure has no causal relationship with GDP and public debt in the short run. It is also apt to highlight that public debt has a positive impact on the inflation rate, meaning that the inflation rate would likely increase alongside a rise in public debt ceteris paribus.

4.2.4 Error correction model-Granger long-run causality. The ECM is estimated to test the long-run causal relationship using $\mathrm{ECT}_{\mathrm{t}-1}$. GDP and investment spending are estimated as dependent variables following the cointegration test result. The results are depicted in Table 5. The results reveal that there is long-run Granger causality running from all the exogenous variables (i.e. public debt, government consumption expenditure, inflation rate, investment spending, trade openness and population growth) to GDP, indicating that the explanatory variables have an impact on GDP. In the same token, Granger causality runs from GDP, public debt, government consumption expenditure, inflation rate, trade openness and population growth to investment spending in the long run.

Restricting to GDP and public debt, in the long run, public debt Granger causes GDP and not vice versa, illustrating the unidirectional impact of public debt on GDP in the long run. This empirical result is consistent with the Keynesian school of thought's hypothesis (Elmendorf and Mankiw, 1999) but contradicts the classical school of thought's proposition (Modigliani, 1961; Diamond, 1965). This finding further rejects the hypothesis of no causality by the REH (Ricardo, 1951) while it is incomparable with the MMT (Mosler, 1993) because the MMT disregard the impact of public debt on GDP in the long run, arguing that the economy will work out itself at full employment.

In contrast with current empirical studies, this finding fails to support the hypothesis that Granger causality runs from GDP to public debt (Donayre and Taivan, 2017; Saungweme and Odhiambo, 2019). Similarly, this finding contradicts prior studies which revealed the negative impact of public debt on GDP (Barro, 1990; Saint-Paul, 1992; Aizenmana et al., 2007; Eberhardt and Presbitero, 2015; Adom, 2016; Ahlborn and Schweickert, 2016; Anning et al., 2016) and no causality (Ahmed et al., 2000; Reinhart and Rogoff, 2010; Jalles, 2011; Panizza and Presbitero, 2014). However, the present finding supports empirical literature which established Granger's long-run positive causal relationship running from public debt to GDP (Maghyereh, 2003; Kumar and Woo, 2010; Egbetunde, 2012; Owusu-Nantwi and Erickson, 2016; Matuka and Asafo, 2018).

In regard to investment spending, the results imply that there is bi-directional Granger causality between investment spending and GDP in the long run. This finding is inconsistent with prior literature by Maghyereh (2003) which established a unidirectional long-run causal relationship running from investment spending to GDP of the Jordanian economy.

4.2.5 Residual and stability diagnostics tests. To confirm the validity of the findings of this study, the stability diagnostic test is carried out using CUSUM (which is suitable for ARDL) at a 5\% significant level. The CUSUM curve shows that the models are stable. For simplicity purpose and focus of key variables, only three dependent variables have been 


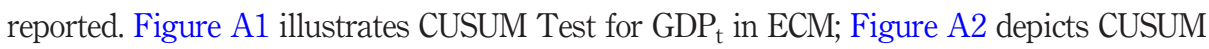
Test for $\mathrm{INV}_{\mathrm{t}}$ in ECM and Figure A3 displays CUSUM Test for $\mathrm{PD}_{\mathrm{t}}$ in the ARDL model.

In addition, a residual diagnostic test is carried out via Breusch-Godfrey serial correlation and heteroskedasticity tests. The results of the two tests are presented in Table 6. The results indicate that the models are not serially correlated and no heteroskedasticity. Thus, the results of this study are valid and reliable to have both theoretical and practical implications, thereby contributing significantly to extant literature.

\section{Implications and concluding remarks}

This paper has made a significant contribution to economic theories by laying empirical support to the REH which argued that public debt has a neutral impact on economic growth. This study also empirically confirms the Keynesian economic theory which suggested that public debt has a positive impact on economic growth. Thus, the present study exposes the unviability of the classical economic theory and MMT in contemporary times, particularly in managing public debt during COVID 19 era in a developing economy context. However, the application of both REH and Keynesian economic theory relative to public debt and economic growth in recent times would likely be viable. That is, recent borrowing will not have an effect on GDP in the short run but it will have a positive impact on GDP in the long run.

Practically, the findings have the following implications on economic policy in a developing economy context (e.g. Ghana) First, government(s) must ensure high fiscal discipline to serve as a precursor for the effective and efficient use of recent borrowing, that is, the loans should be used for highly prioritized projects (preferably infrastructure or investment spending) that are well evaluated and self-sustained to add positively to the GDP. Further, government(s) must not be anxious about an economic turnaround in the short-run as investment spending will quite stifle GDP; however, there will be a significant positive turnaround in the long run. Again, the use of debt to finance consumption expenditure should be limited to ensure sustainable economic growth. Finally, government (s) should expect the inflation rate to increase alongside an increase in debt stock in the short run but the situation will likely change in the long run.

In conclusion, this paper examined the impact of public debt on economic growth (GDP) in a developing economy context using Ghana as a case study due to the continuous rise in the public debt of Ghana with unstable GDP growth rate and the recent impact of COVID 19 on the global economy which resulted in massive borrowing by countries, particularly

\begin{tabular}{|c|c|c|}
\hline Dependent variable & $\frac{\text { Serial correlation LM }}{F \text {-statistic [Prob. F] }}$ & $\frac{\text { Heteroskedasticity }}{F \text {-statistic [Prob. F] }}$ \\
\hline $\mathrm{GDP}_{\mathrm{t}}$ & $2.651488[0.1160]$ & $0.740823[0.6399]$ \\
\hline $\mathrm{PD}_{\mathrm{t}}$ & $0.925862[0.4164]$ & $0.734236[0.7181]$ \\
\hline GOVE $_{\mathrm{t}}$ & $0.034031[0.8551]$ & $0.231425[0.9738]$ \\
\hline $\mathrm{INF}_{\mathrm{t}}$ & $1.760789[0.2036]$ & $0.492691[0.9080]$ \\
\hline $\mathrm{INV}_{\mathrm{t}}$ & $1.941837[0.1758]$ & $0.622894[0.8134]$ \\
\hline $\mathrm{OPEN}_{\mathrm{t}}$ & $0.430012[0.7380]$ & $0.329780[0.9845]$ \\
\hline $\mathrm{POPG}_{\mathrm{t}}$ & 0.004004 [0.9598] & $0.236429[0.9752]$ \\
\hline$* \mathrm{GDP}_{\mathrm{t}}$ & $1.112663[0.3020]$ & $0.769987[0.6321]$ \\
\hline$* \mathrm{INV}_{\mathrm{t}}$ & $0.360662[0.7014]$ & $0.756825[0.6428]$ \\
\hline
\end{tabular}

Note: ${ }^{*} \mathrm{GDP}_{\mathrm{t}}$ and, ${ }^{\mathrm{INV}} \mathrm{t}$ are for the $\mathrm{ECT}_{\mathrm{t}-1}$
Public debt and economic growth

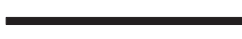


AJEB

5,2

developing countries. ARDL model and ECM were used to test for the Granger causality between public debt and GDP. The empirical results reveal that public debt has no causal relationship with GDP in the short-run; however, public debt Granger causes GDP in the long-run, ceteris paribus. These findings are not without precedents as some reviewed studies equally established no causality in the short-run but unidirectional Granger causality in the long-run in both developed and developing economies. Therefore, public debt does not contribute to economic growth in Ghana in the short-run but it does contribute in the long run. It is also instructive to note that investment spending has a negative bidirectional causal relationship with GDP in the short-run but they have a positive bidirectional causal relationship in the long run. On the other hand, government consumption expenditure has no causal relationship with GDP in the short-run but Granger causality runs from government consumption expenditure to GDP in the long run. Finally, public debt has a positive impact on the inflation rate in the short run.

\section{Limitations and future research directions}

In spite of the significant contribution of this paper to the extant literature, the following limitation needs to be highlighted. The scope of the paper (i.e. the focus on one developing country) limits the extent of generalization of the findings and further implies that application of the findings in other jurisdictions must be done cautiously. Hence, future research should examine the phenomenon in selected developing countries, perhaps, in SubSahara Africa to see whether there will be differences in the findings and also allow for greater generalization and applicability.

\section{References}

Abbas, A.S.M. and Christensen, J.E. (2007), "The role of domestic debt markets in economic growth: an empirical investigation for low-income countries and emerging markets", IMF Working Papers IMF, 07/127, International Monetary Fund, Washington, DC.

Adom, P. (2016), "The DDT effect: the case of economic growth, public debt and democracy relationship", Munich Personal RePEc Archive, Vol. 75022, pp. 1-35.

Afzal, M. (2012), "Ricardian equivalence hypothesis: evidence from Pakistan", Journal of Business Management and Economics, Vol. 3 No. 6, pp. 258-265.

Ahlborn, M. and Schweickert, R. (2016), "Public debt and economic growth - economic systems matter", (Center for European, Governance and Economic Development Research Discussion Papers 281), University of Goettingen, Göttingen.

Ahmed, Q., Butt, M., Sabihuddin, M. and Shaista, A. (2000), "Economic growth, export and external debt causality: the case of Asian countries", The Pakistan Development Review, Vol. 39 No. 4II, pp. 591-608.

Aizenmana, J., Pinto, B. and Radziwill, A. (2007), "Sources for financing domestic capital - is foreign saving a viable option for developing countries?", Journal of International Money and Finance, Vol. 26 No. 5, pp. $682-702$.

Amoateng, K. and Amoako-Adu, B. (1996), "Economic growth, export and external debt causality: the case of African countries", Applied Economics, Vol. 28 No. 1, pp. 21-27.

Amponsah, K.T. (2015), “Ghana's public debt and financial development”, 六甲台論集. 国際協力㸴 究編, Vol. 16, pp. 25-54.

Anning, L., Ofori, C. and Affum, E. (2016), "The impact of government on the economic growth of Ghana: a time-series analysis from 1990-2015”, International Journal of Innovation and Economic Development, Vol. 2 No. 5, pp. 31-39. 
Barro, R. (1979), "On the determination of public debt", Journal of Political Economy, Vol. 87 No. 5, Part 1, pp. 240-271.

Barro, R.J. (1990), "Government spending in a simple model of endogenous growth", Journal of Political Economics, Vol. 98 Nos 5/2, pp. 103-125.

BoG (2020), January 2020 Bank of Ghana's summary of financial and economic data: Monetary Policy Committee Report, Author, Accra.

Broner, F., Aitor, E., Alberto, M. and Jaume, V. (2014), "Sovereign debt markets in turbulent times: creditor discrimination and crowding-out effects", Journal of Monetary Economics, Vol. 61, pp. 114-142.

Castro, G., Félix, R.M., Júlio, P. and Maria, J.R. (2015), "Unpleasant debt dynamics: can fiscal consolidation raise debt ratios?", Journal of Macroeconomics, Vol. 44, pp. 276-294.

Cochrane, J.H. (2011), "Understanding policy in the great recession: some unpleasant fiscal arithmetic", European Economic Review, Vol. 55 No. 1, pp. 2-30.

Diamond, P. (1965), "National debt in a neoclassical growth model”, American Economic Review, Vol. 55 No. 5, pp. 1126-1150.

Dickey, D.A. and Fuller, W.A. (1981), "Likelihood ratio statistics for autoregressive time series with unit root", Econometrica, Vol. 49, pp. 1057-1072.

Domar, E.D. (1944), "The burden of the debt and the national income", American Economic Review, Vol. 34, pp. 798-827.

Donayre, L. and Taivan, A. (2017), "Causality between public debt and real growth in the OECD: a country-by country analysis", Economic Papers: A Journal of Applied Economics and Policy, Vol. 36 No. 2, pp. 156-170.

Driessen, G.A. and Gravelle, J.G. (2019), "Deficit financing, the debt, and "modern monetary theory", Congressional Research Service, pp. 1-23.

Eberhardt, M. and Presbitero, A.F. (2015), "Public debt and growth: heterogeneity and non- linearity", Journal of International Economics, Vol. 97 No. 1, pp. 45-58.

Egbetunde, T. (2012), "Public debt and economic growth in Nigeria: evidence from granger causality", American Journal of Economics, Vol. 2 No. 6, pp. 101-106.

Elmendorf, D.W. and Mankiw, G.N. (1999), “Government debt”, in Taylor, J.B. and Woodford, M. (Eds), Handbook of Macroeconomics, Harvard University.

Ewaida, H.Y.M. (2017), "The impact of sovereign debt on growth: an empirical study on GIIPS versus JUUSD countries", European Research Studies Journal, Vol. 20 No. 2A, pp. 607-633.

Ferreira, C. (2009), "Public debt and economic growth: a granger causality panel data approach", Instituto Superior De Economia E GestãoWorking Paper. No. 24/2009, School of Economics and Management, Department of Economics, Lisbon.

Ghana Health Service (2020), COVID-19 update, available at: www.ghanahealthservice.org/covid19/ (accessed 23 May 2020).

Gómez-Puig, M. and Sosvilla-Rivero, S. (2018), "Public debt and economic growth: further evidence for the euro area”, Acta Oeconomica, Vol. 68 No. 2, pp. 209-229.

Gómez-Puig, M. and Sosvilla-Rivero, S. (2015), "The causal relationship between public debt and economic growth in EMU countries", Journal of Policy Modeling, Vol. 37 No. 6, pp. 974-989.

Granger, C.W.J. and Newfold, P. (1974), "Spurious regressions in econometrics", Journal of Econometrics, Vol. 2 No. 2, pp. 111-120.

Huang, Y., Panizza, U. and Varghese, R. (2018), "Does public debt crowd out corporate investment? International evidence”, (IHEID Working Papers 08-2018), Economics Section, The Graduate Institute of International Studies.

IMF (1984), International Financial Statistics Yearbook, Author, Washington, DC.

IMF (2015), Regional Economic Outlook: Sub-Sahara Africa, Author, Washington, DC. 
AJEB

5,2

IMF (2020), International Debt Statistics Database, Author, Washington, DC.

Jalles, J.T. (2011), "The impact of democracy and corruption on the debt-growth relationship in developing countries", Journal of Economic Development, Vol. 36 No. 4, pp. 41-72.

Kobayashi, K. (2015), "Public debt overhang and economic growth, policy research institute, ministry of finance", Japan. Public Policy Review, Vol. 11 No. 2, pp. 247-276.

Kobayashi, K. and Shirai, D. (2017), "Debt-ridden borrowers and economic slowdown”, (CIGSWorking Paper 17-002E), The Canon Institute for Global Studies.

Kourtellos, A., Stengos, T. and Tan, C.M. (2013), "The effect of public debt on growth in multiple regimes", Journal of Macroeconomics, Vol. 38 No. 8, pp. 35-43.

Krugman, P. (1988), "Financing vs. forgiving a debt overhang", Journal of Development Economics, Vol. 29 No. 3, pp. 253-268.

Krumm, L.K. (1985), "The external debt of Sub-Saharan africa: origins, magnitude, and implications for action", Working Paper, 741, World Bank, Washington, DC.

Kumar, M. and Woo, J. (2010), "Public debt and growth", IMF Working Paper 10/174.

Lamont, O. (1995), "Corporate-debt overhang and macroeconomic expectations”, American Economic Review, Vol. 85 No. 5, pp. 1106-1117.

Lutkepohl, H. (1982), "Non-causality due to omitted variables", Journal of Econometrics, Vol. 19, pp. 367-378.

Maghyereh, A.I. (2003), "External debt and economic growth in Jordan: the threshold effect", International Economics, Vol. 56 No. 3, pp. 337-355.

Mankiw, N.G. (2000), "The savers-spenders theory of fiscal policy", American Economic Review Papers Review, Vol. 90 No. 2, pp. 120-125.

Marquez, N. (2000), "Debt sustainability in the ECCB area”, Social and Economic Studies, Vol. 49 Nos 2/3, pp. $77-108$.

Matuka, A. and Asafo, S.S. (2018), "External debt and economic growth in Ghana: a co-integration and a vector error correction analysis", Munich Personal RePEc Archive, Paper No. 90463.

Modigliani, F. (1961), "Long-run implications of alternative fiscal policies and the burden of the national debt", The Economic Journal, Vol. 71 No. 284, pp. 730-755.

Mosler, W. (1993), Soft Currency Economics II: The Origin of Modern Monetary Theory (MMTModern Monetary Theory).

Ncanywa, T. and Masoga, M.M. (2018), "Can public debt stimulate public investment and economic growth in South Africa?”, Cogent Economics and Finance, Vol. 6, pp. 1-13.

Nwannebuike, U.S., Ike, U.J. and Onuka, O.I. (2016), "External debt and economic growth: the Nigeria experience", European Journal of Accounting Auditing and Finance Research, Vol. 4 No. 2, pp. 33-48.

Ogunmuyiwa, M.S. (2010), "Does external debt promote economic growth in Nigeria?", Current Research Journal of Economic Theory, Vol. 3 No. 1, pp. 29-35.

Onogbosele, D.O. and Ben, M.D. (2016), "The impact of domestic debt on economic growth of Nigeria", Asian Research Journal of Arts and Social Sciences, Vol. 1 No. 3, pp. 1-13.

Owusu-Nantwi, V. and Erickson, C. (2016), "Public debt and economic growth in Ghana", African Development Review, Vol. 28 No. 1, pp. 116-126.

Panizza, U. and Presbitero, A.F. (2014), "Public debt and economic growth: is there a causal effect?", Journal of Macroeconomics, Vol. 41, pp. 21-41.

Pesaran, M.H., Shin, Y. and Smith, R. (2001), "Bound testing approaches to the analysis of level relationship", Journal of Applied Econometrics, Vol. 16 No. 3, pp. 289-326.

Phillips, P.C.B. (1986), "Understanding spurious regressions in econometrics", Journal of Econometrics, Vol. 33 No. 3, pp. 311-340. 
Reinhart, C.M., Reinhart, V.R. and Rogoff, K.S. (2012), "Public debt overhangs: advanced- economy episodes since 1800", Journal of Economic Perspectives, Vol. 26 No. 3, pp. 69-86.

Reinhart, C.M. and Rogoff, K.S. (2010), "Growth in a time of debt”, NBER Working Paper No. 15639.

Ricardo, D. (1951), "On the principles of political economy and taxation”, in Sraffa, P. (Ed.), The Works and Correspondence of David Ricardo, Vol. 1, Cambridge University Press, Cambridge, with the collaboration of M. Dobb.

Saint-Paul, G. (1992), "Fiscal policy in an endogenous growth model", The Quarterly Journal of Economics, Vol. 107 No. 4, pp. 1243-1259.

Saungweme, T. and Odhiambo, N.M. (2019), "Government debt, government debt service and economic growth nexus in Zambia: a multivariate analysis", Cogent Economics and Finance, Vol. 7 No. 1, pp. 1-17.

Stambuli, P.K. (1998), “Causes and consequences of the 1982 world debt crisis”, Predoctoral Research Paper Department of Economics University of Surrey Guildford, pp. 1-35.

Wagner, A. (1911), The State in Economic Perspective, 3rd ed., Hinsicht.

World Bank (2004), Ghana-Enhanced Heavily Indebted Poor Countries (HIPC) Debt Initiative(English), World Bank, Washington, DC.

World Bank (2020), "World bank databank", World Development Indicators. [Online], available at: www.data.worldbank.org (accessed 07 February 2020).

Wray, R.L. (2015), Modern Monetary Theory: A Primer on Macroeconomics for Sovereign Monetary Systems, 2nd ed., Palgrave Macmillan, New York, NY.

Wray, R.L. (1998), Understanding Modern Money: The Key to Full Employment and Price Stability, Edward Elgar, Northampton, Mass.

\section{Further reading}

Checherita-Westphal, C. and Rother, P. (2012), "The impact of high government debt on economic growth and its channels: an empirical investigation for the euro area", European Economic Review, Vol. 56 No. 7, pp. 1392-1405.

Egert, B. (2015), "Public debt, economic growth and nonlinear effects: myth or reality?", Journal of Macroeconomics, Vol. 43, pp. 226-238.

Engle, R.F. and Granger, C.J. (1987), "Cointegration and error-correction - representation, estimation and testing”, Econometrica, Vol. 55 No. 2, pp. 251-278.

Mencinger, J., Aristornik, A. and Verbic, M. (2014), "The impact of growing public debt on economic growth in the European union", Amfiteatru Economics, Vol. 16 No. 35, pp. 403-414. 
AJEB

\section{Appendix}

5,2

\section{2}

Figure A1.

Stability diagnosticCUSUM test for GDPt in $\mathrm{ECM}$

Figure A2.

Stability diagnostic CUSUM test for INVt in ECM
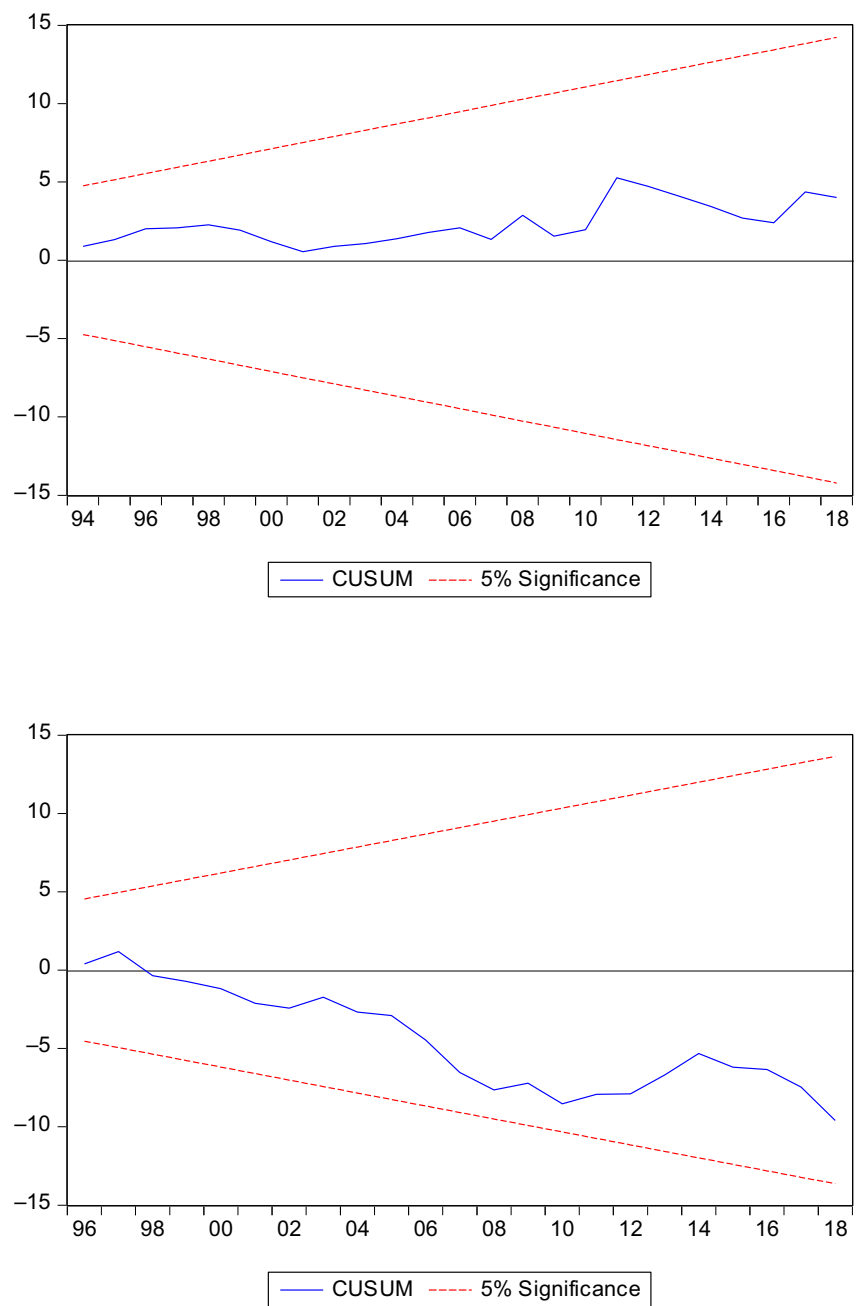


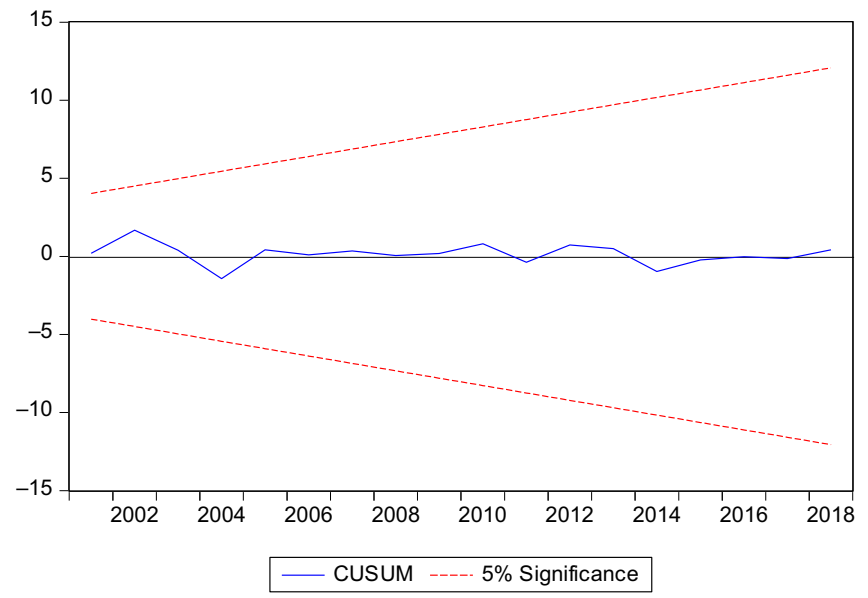

Public debt and economic growth

\section{Corresponding author}

Sam Kris Hilton can be contacted at: krishiltons@gmail.com

For instructions on how to order reprints of this article, please visit our website: www.emeraldgrouppublishing.com/licensing/reprints.htm Or contact us for further details: permissions@emeraldinsight.com 